\title{
Employability Skills Based on Polytechnic Graduate Job Role: Immediate Supervisor Perception
}

\author{
Normala Rahmat ${ }^{1}$, Yahya Buntat ${ }^{1} \&$ Abdul Rahman Ayub ${ }^{2}$ \\ ${ }^{1}$ Department of Technical and Vocational Education, Faculty of Education, Universiti Teknologi Malaysia, Johor, \\ Malaysia \\ ${ }^{2}$ Department of Quality Surveying and Real Estate, Faculty of Engineering and Built Environment, Tunku Abdul \\ Rahman University College (TARC), Kuala Lumpur, Malaysia \\ Correspondence: Normala Rahmat, Department of Technical and Vocational Education, Faculty of Education, \\ Universiti Teknologi Malaysia, Johor, Malaysia. Tel: 60-134-897-745. E-mail: normala74@ gmail.com
}

Received: August 1, 2018

doi:10.5539/ass.v14n11p30
Accepted: September 1, $2018 \quad$ Online Published: October 22, 2018

URL: https://doi.org/10.5539/ass.v14n11p30

\begin{abstract}
Twenty first century employers need quality graduates to be competitive in global currents. This study was conducted to identify the importance of employability skills constructs required to improve the work performance based on the perception of the immediate supervisor's in the polytechnic electronic graduates' job role. This study uses a descriptive survey study involving a quantitative approach. Data collection was done by obtaining and analyzing quantitative data through self-developed questionnaire consisting of 31 items based on seven constructs of employability skills such as communication skills; personal qualities; teamwork skills; critical thinking skills and problem solving; technology skills; organizational skills and continuous learning skills. The sample consists of 170 immediate supervisors who represent the employers in four units of electrical and electronics industries namely research and development unit, maintenance unit, production unit and; quality and assurance unit. The findings of the quantitative study were analyzed using the Winstep V3.69.1.11 software. The findings of the analysis of the importance level of employability skills construct needed to improve work performance in all units are high with different priority rankings based on the role of graduates in the unit. In addition, the findings also show that critical thinking skills and problem solving are the most important employability skill constructs as well as the personal qualities and the latter are technology skills that must be owned and possesses by graduates who choose career paths in the electrical and electronic industries. Therefore, with the clarity of the concept of employability skills based on the job role as a result of this study it will facilitate graduates to adapt to the current wave of industrial change towards the concept of industry 4.0 with the application of precise employability skills oriented in the polytechnic electrical engineering curriculum.
\end{abstract}

Keywords: employability skills, job role, immediate supervisor perception

\section{Introduction}

Employers in the 21st century look for candidates who have high competitiveness and are able to adapt to the rapid changes in the industry rather than just having good academic achievement (Rasul et al., 2009; Yusoff et al., 2010; Johari et al., 2011; Hamzah \& Abdullah; Selvadurai et al., 2012). Employers emphasize that graduates lack the employability skills required by employers (Junaidah, 2012; Ministry of Higher Education Malaysia, 2012). This is due to the failure of development and the mastery of employability skills while they are in institutions of study and this can inhibit their transfer in the work environment (Tymon, 2011). The employer considers that graduates are still not ready to enter and face the complexity and challenges of the world of work (Tymon, 2011; Junaidah, 2012) and the inability to make graduates unskillful in performing work procedures (Tetreault, 1997). Martin, A. J., Milne-Home, J., Barrett, J., Spalding, E. \& Jones (2000) in his study found that universities face difficulties in educating and training their students who will handle the needs of employers. The presence of these skills gaps has put pressure on institutions of higher learning to consider how the academy can play an important role in providing graduates to prepare for the labor market needs and challenges (Martin, Milne-Home, Barrett, Spalding, \& Jones, 2000).

In Malaysia, the skills gap still existed between institutions of study and employers as conducted by Hamzah \& Abdullah (2012); found that employability skills gap among graduates are at moderate level, as well as studies 
by Husain et al. (2013) show the level of mastering of employability skills of technical institution students especially polytechnics from employer's perspective is still at moderate level. It is predictable that graduates employability profile in Malaysia is still low. This statement is also supported by Kivinen \& Silvennoinen (2002) research who have identified the skill gaps inherent in college graduates and the skills level of graduates does not meet the required level of job entry which is one of the causes of increasing unemployment among graduates. The unemployment problem of engineering graduates is not a new thing as the study by Syed Hussain (2005) and Mohamed Rashid (2005) on polytechnic graduates also found that about 50.5\% of polytechnic technical graduates were unemployed during the first nine months of the year as they lacked employability skills. A study by Ahmad Nabil (2012) also found that the unemployment phenomenon of technical graduates especially engineering is closely related to the lack of employability skills.

To succeed in today's complex, dynamic, interconnected and global world, engineering professionals and graduates not only need a solid foundation in engineering technical skills but also additional competencies such as leadership, co-operation, creativity, and problem-solving skills (Ahn, Pearce, \& Kwon, 2012). Engineering education in Malaysia has long been regarded as a process of character screening and skills to work at the workplace (Yusoff et al., 2010). Accordingly, Hamzah \& Abdullah (2012) and N. H. Omar et al. (2012) states that in order to improve the quality of future graduates and to create more productive and innovative human capital for various disciplines, the educational institutions and graduates should be prepared to enhance employability skills by market niche areas. Since the industry is not a single entity, there is no agreement on the proper inventory of employability skills that graduates need (Pillai, Khan, Syahirah, \& Raphael, 2012).

Based on the National Key Economic Area (NKEA) report as noted in The National Graduate Employability 2012-2017 (Ministry of Higher Education, 2012), there are no detailed details on the attributes that need to be formed or the characteristics of the workers required except for professional courses. This industry demand will not be met as long as the details of the permanent properties are not resolved. Institutions of study need to enhance the relationship with the industrial sector to know the skills required by employers when they employ workers (Kivinen dan Silvennoinen 2002; Abas-Mastura, Ombra A. Imam, et al., 2013). Employers are experts on the skills requirement in their organization so that institutions cannot ignore their complaints about the quality of the graduates produced. The institutions of higher learning can maximize the knowledge shared by the employers for future training of graduates as suggested by Evers et al. (1998). A. Fairuzza et al., (2011); Mohd Izyan et al., (2012); Rosenberg et al., (2012) dan Abas-Mastura, Ombra A. Imam, et al., (2013) stated that closer co-operation and partnership between institutions of study and employment institutions became more important today than ever before to resolve the gap skills.

In this regard, as the effort to strengthen the quality of graduates, the study of employability requires continuous effort so that the institutions of learning can learn the skills change, especially the employability skills required by the employers. There are various studies that have been conducted towards obtaining views from the employers including studies by Rasul et al. (2009); Y.M. Yusoff et al., (2010) and Husain et al.(2013),but there is no study that explores the employability skills required by the employers from their perceptions that apply to them as immediate supervisor based on the role of work affecting the performance in specific industries namely the electrical and electronics industries in line with the changing concept of the basic concept of employability skills that are now more work-oriented contexts (Sung, Ng, Loke, \& Ramos, 2013). This statement along with Stasz (1997), study found that employability skills constructs cannot be seen in general across all occupations but instead it should be based on the role of work, especially those requiring high skills such as engineering. This is because the employer's job offer is dependent on the possession of appropriate employability skills by graduates for a desired job role (Dafou, 2009).

\subsection{Employability Skills Models}

There are various prior study models on the aspects of employability skills required by employers. Among the models of the study are the Model of the Study of the Commission's Commission on Achieving Necessary Skills (2001), The European Round Table of Industrialists (ERT) (DEST, 2002), Model Employability Skills 2000+ by The Conference Board of Canada's Employability Skills Forum and the Business and Education Forum on Science, Technology and Mathematics, Australian Government Department of Education Employment and Workplace Relations (2008) and Top 10 Employability Skills by Science Technology Engineering and Mathematics Network (STEMNET), (2013)

The SCANS (2001) model divides employability skills into two main divisions, namely basic skills and skills in the workplace. Basic Skills consists of three sub-divisions namely basic skills (reading, writing, arithmetic or math, listening and speaking); thinking skills (thinking creatively, making decisions, solving problems, reasoning, 
how to learn and making judgments) and individual qualities (showing responsibility, self-esteem, social skills, self-management skills, integrity and honesty). Workplace skills consist of five sub-divisions namely resource skills (identifying, managing, designing and placing sources in place); interpersonal skills (working skills with others); information skills (acquiring skills and using information); system skills (complex understanding of communication skills), and technological skills (working skills with various technologies).

The Conference Board of Canada (2000) has issued the Employability Skills 2000+ guidelines to provide graduates with the opportunity to enter the world of work, to remain and be effective in carrying out their task of comprising three divisions namely Basic Skills; Personalized Management Skills and Teamwork Skills. Basic Skills consist of communication, using numbers, managing information, thinking and solving problems. Personal Management Skills consist of demonstrating positive attitude, responsibility, adaptive skills, lifelong learning and working safely. Teamwork Skills include the ability to work with others and engage in projects and tasks.

The Australian Government Department of Education Employment and Workplace Realty (2008) has identified eight groups of employability skills from the Employability Skills Framework in the manufacturing industry in Australia: (1) Communication skills that contribute to productive and harmonious relationships between employers and employees; Working group skills contributing to productive work relationships, (3) Problem solving skills that contribute to productive outcomes, (4) Corporate skills and initiatives that contribute to innovative outcomes, (5) Creating and organizing skills that contribute to long-term and short strategic plans, (6) Self-management skills that contribute to employer and employee satisfaction, (7) Learning skills that contribute to the continuous improvement of employers and employees in the company's operations, (8) Technological skills that contribute to effectiveness execution in a task.

STEMNET (2013) states that "Top 10 Employability Skills" sought by employers in the United Kingdom on potential employees are communication and interpersonal skills, problem solving skills, initiative and self-motivation, working under pressure and deadlines, organizational skills, teamwork, the ability to learn and adjust, numeracy, value diversity and differences and consulting skills.

Based on the combined models mentioned above, researchers have summarized seven constructs of employability skills to be used as independent variables. The seven constructs of employability skills to be used in this study are:

- Communication skills

- Personal Quality

- Teamwork Skills

- Critical Thinking Skills and Problem Solving

- Technology Skills

- Organizational Skills

- Continuous Learning Skills

\subsection{Job Roles}

Skills are the ability to perform certain tasks by graduates to make them qualified in the employer's view (DEST, 2006; Prakash, 2012). Emphasis on skills required by employers will vary depending on the type of job roles that will be implemented in an organization and also depending on the way and style they work in achieving their goals (Raybould dan Sheedy, 2005; Prakash, 2012). There are transferable skills that the employer wants to see to the graduates and they vary according to the type of role; and in general, employers also want to see graduates interested in continuing to develop their skills (Raybould \& Sheedy, 2005). According to Raybould dan Sheedy (2005), there are some disagreements about the importance of skills that can be "transferred" or "workable" to employees. These skills refer to individual personal abilities, which can be taken from one another role, used in any profession and at any level of their careers.

This statement coincides with the Action and Performance Theory, as shown in Figure 1 which is the basis for the concept of efficiency. Maximum performance is believed to occur when the individual's capabilities or talents are in line with job demands and the organization's environment (Boyatzis, 2008). The individual talents was described are personal values, vision, and philosophy, knowledge of competence; life and career rankings; interests and styles that are part of the elements of employability skills. Job Demand includes tasks, functions and roles that need to be done. While aspects of the organization's predicted environments have important implications for demonstration of competence or design of one-off work including culture and climate, structure and systems; industrial maturity and strategic positioning within it; and that aspect, political, social, 
environmental, economic and religious environment around the organization. Accordingly, based on this theory, researchers are exploring the importance of applying construct skills construct based on the role of work that can improve the performance of polytechnic electronic graduates as technicians in the electrical and electronics industries.

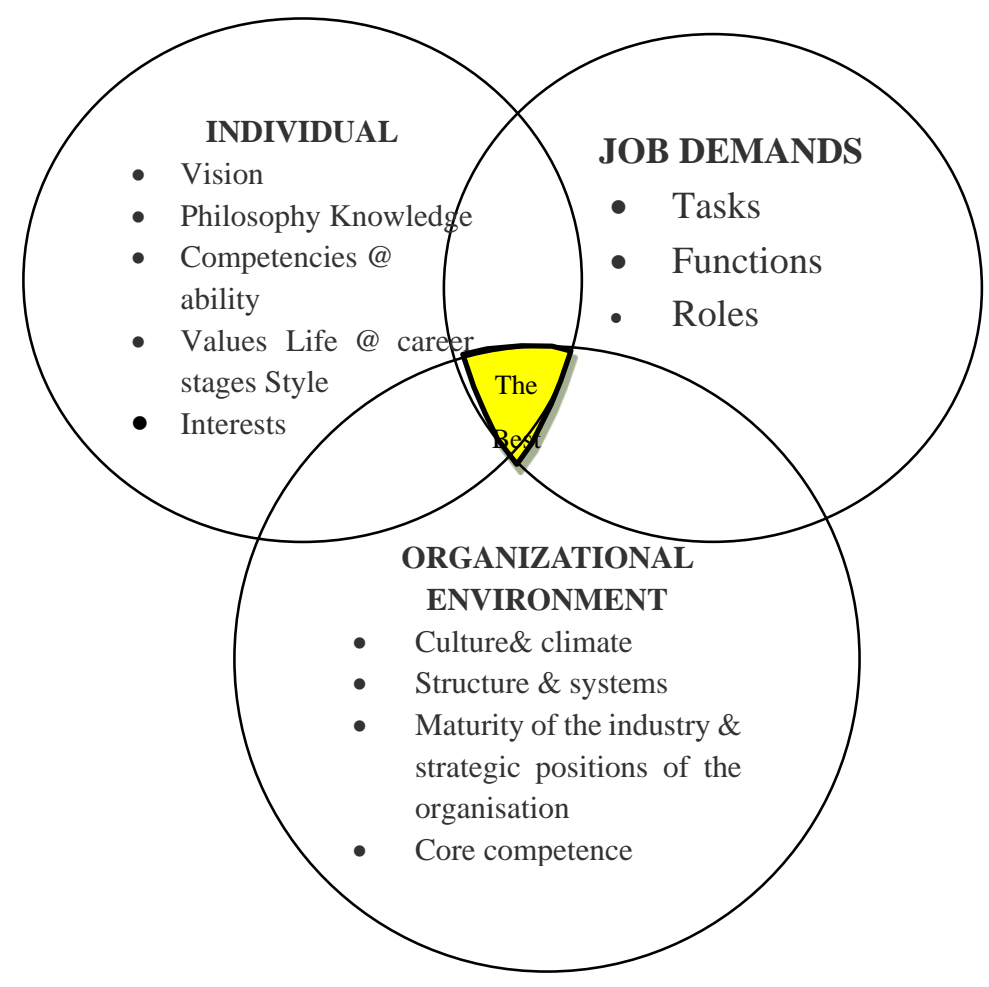

Figure 1. The Action and Performance Theory (Boyatzis, 2008).

\subsection{Research Objective}

Through this study, the researcher wants to identify the importance of constructing constructability skills based on the objectives below;

1) Identify the important level of employability skills construct required to improve work performance based on work performance based on the perceptions of the immediate supervisor's in the polytechnic electronic graduates' job role.

2) Identify the most dominant constructs of employability skills towards improving the work performance of polytechnic electronic graduates.

\subsection{Research Question}

Based on the objectives of the following study, the question of the study can be established;

1) To what extent the important level of employability skills construct is necessary towards improving the work performance based on the perception of the immediate supervisor's in the polytechnic electronic graduates' job role?

2) To what extent the important level of the most dominant constructs of employability skills contributes towards improving work performance of polytechnic electronic graduates

\section{Method}

This study uses a descriptive survey study involving a quantitative approach to evaluate the importance level of employability skills construct required to improve work performance based on the perception of the immediate supervisors' in the polytechnic electronic graduates' job role. Survey-based surveys using questionnaires were used by researchers as this method was effective and practical to obtain good feedback from respondents in a short period of time (Talib, 2009; Azman, 2012). The questionnaire consisted of 31 items based on seven constructs of employability skills i.e. communication skills; personal qualities; teamwork skills; critical thinking 
skills and problem solving; technology skills; organizational skills and continuous learning skills.

\subsection{Sample of Study}

Population for this study consists of employers of electrical and electronic products manufacturing industries who have employees comprising diploma graduates from 2010 to 2013 from polytechnics who offer engineering courses. Employers involved in this study are divided into three demographics:

1) by industry type namely electrical and electronic products manufacturing industry

2) according to company size

3) by the ownership status of the company

A total of 170 immediate supervisors represented the employers in four units of electrical and electronics industries, namely unit research and development, unit maintenance, unit production and unit quality and assurance being survey respondents.

\subsection{Instrument of Study}

In this study, researchers have developed questionnaire instruments by forming sub-constructs based on seven constructs of employability skills i.e. communication skills; personal qualities; teamwork skills; critical thinking skills and problem solving; technology skills; organizational skills and continuous learning skills. The construction of items for this research instrument is carried out after the constructed constructions have been approved by experts. For the next step, items are developed with a perception assessment where five-point Likert scales are used as suggested by Konting (1990), Uma Sekaran (2000) and Esa (2006), which are as Table 1. Based on Bond \& Fox (2007), this Likert scale attempts to measure the level of perception of respondents' perceptions through constructed items. This questionnaire contains 31 items based on seven constructs of employability skills as independent variables aimed at obtaining feedback on the importance level of employability skills required to improve the performance of polytechnic electronic graduates in the electrical and electronic industries.

Table 1. Scoring Likert Scale

\begin{tabular}{cc}
\hline LIKERT SCALE & LEVEL OF IMPORTANT \\
\hline 1 & Extremely Unnecessary \\
2 & Unnecessary \\
3 & Moderately Necessary \\
4 & Necessary \\
5 & Extremely Necessary \\
\hline
\end{tabular}

\section{Results}

The findings of this study were conducted by involving 170 immediate supervisors in four units of electrical and electronic industries namely unit research and development, unit maintenance, unit production and unit quality and assurance aimed at responding to questions 1 and 2. Winstep V3.69.1.11 software is based on mean measure (logit) and mean score.

\subsection{Analysis the Important Level of Employability Skills Construct at Research and Development Unit}

Table 2. Analyze the Important Level of Employability Skills Construct at Unit Research and Development

\begin{tabular}{cccc}
\hline EMPLOYABILITY SKILLS CONTRUCT & MEAN MEASURE (LOGIT) & MEAN SCORE & LEVEL \\
\hline Critical Thinking Skills and Problem Solving & -0.72 & 4.49 & HIGH \\
Personal Quality & -0.64 & 4.46 & HIGH \\
Communication Skills & -0.10 & 4.31 & HIGH \\
Organizational Skills & 0.11 & 4.25 & HIGH \\
Continuous Learning Skills & 0.20 & 4.22 & HIGH \\
Teamwork Skills & 0.42 & 4.15 & HIGH \\
Technology Skills & 0.61 & 4.09 & HIGH \\
\hline
\end{tabular}


The results of the analysis show the important level of employability skills construct required to improve work performance based on the perception of immediate supervisor's in the Research and Development unit at high levels. The immediate supervisor puts critical thinking skills and problem solving on the first rank with mean measure $=-0.72$ logit and mean score $=4.49$; The next ranking is personal quality with mean measure $=-0.64$ logit and mean score $=4.46$; communication skills with mean measure $=-0.10$ logit and mean score $=4.31$; organizational skills with mean measure $=0.11$ logit and mean score $=4.25$; continuous learning skills with mean measure $=0.20$ and mean score $=4.22$; teamwork skills with mean measure $=0.42$ and mean score $=4.15$; and the final ranking construct is technology skill with mean measure $=0.61$ and mean score $=4.09$. The level analysis of employability skills constructs is shown in Table 2.

\subsection{Analysis the Important Level of Employability Skills Construct at Maintenance Unit}

The result of the analysis shows the important level of employability skills construct required to improve the performance of the work based on the perception of the immediate supervisor in the Maintenance unit at a high level. Immediate supervisors place critical thinking skills and problem solving on the first rank with mean measure $=-0.67$ logit and mean score $=4.55$; The next ranking is personal quality with mean measure $=-0.66$ logit and mean score $=4.54$; continuous learning skills with mean measure $=-0.17$ and mean score $=4.45$; communication skills with mean measure $=0.15$ logit and mean score $=4.37$; organizational skills with mean measure $=0.22$ logit and mean score $=4.36$; teamwork skills with mean measure $=0.34$ and mean score $=4.33$; and the final ranking construct is technological skill with mean measure $=0.51$ and mean score $=4.29$. The level analysis of employability skills constructs is shown in Table 3.

Table 3. Analyze the Important Level of Employability Skills Construct at Maintenance Unit

\begin{tabular}{cccc}
\hline EMPLOYABILITY SKILLS CONTRUCT & MEAN MEASURE (LOGIT) & MEAN SCORE & LEVEL \\
\hline Critical Thinking Skills and Problem Solving & -0.67 & 4.55 & HIGH \\
Personal Quality & -0.66 & 4.54 & HIGH \\
Continuous Learning Skills & -0.17 & 4.45 & HIGH \\
Communication Skills & 0.15 & 4.37 & HIGH \\
Organizational Skills & 0.22 & 4.36 & HIGH \\
Teamwork Skills & 0.34 & 4.33 & HIGH \\
Technology Skills & 0.51 & 4.29 & HIGH \\
\hline
\end{tabular}

\subsection{Analysis the Important Level of Employability Skills Construct at Production Unit}

The results of the analysis the important level of employability skills construct required to improve work performance based on the perception of immediate supervisor's in Production units as well as at high levels. Immediate supervisor puts critical thinking skills and problem solving on the first rank i.e. mean measure $=-0.82$ logit and mean score $=4.55$; The next ranking is personal quality with mean measure $=-0.32$ logit and mean score $=4.44$; communication skills with mean measure $=-0.11$ logit and mean score $=4.39$; teamwork skills with mean measure $=0.09$ and mean score $=4.36$; organizational skills with mean measure $=0.27$ logit and mean score $=4.32$; continuous learning skills with mean measure $=0.29$ and mean score $=4.31$; and the final ranking construct is technological skill with mean measure $=0.56$ and mean score $=4.25$. The level analysis of employability skills constructs is shown in Table 4.

Table 4. Analyze the Important Level of Employability Skills Construct at Production Unit

\begin{tabular}{cccc}
\hline EMPLOYABILITY SKILLS CONTRUCT & MEAN MEASURE (LOGIT) & MEAN SCORE & LEVEL \\
\hline Critical Thinking Skills and Problem Solving & -0.82 & 4.55 & HIGH \\
Personal Quality & -0.32 & 4.44 & HIGH \\
Communication Skills & -0.11 & 4.39 & HIGH \\
Teamwork Skills & 0.09 & 4.36 & HIGH \\
Organizational Skills & 0.27 & 4.32 & HIGH \\
Continuous Learning Skills & 0.29 & 4.31 & HIGH \\
Technology Skills & 0.56 & 4.25 & HIGH \\
\hline
\end{tabular}




\subsection{Analysis the Important Level of Employability Skills Construct at Quality and Assurance Unit}

The results of the analysis show the important level of employability skills construct required to improve work performance based on the perception of immediate supervisor's in Unit Quality Assurance at high level. Supervisors have placed personal qualities on the first rank of mean measure $=-0.86$ logit and min score $=4.60$; second ranking is critical thinking skills and problem solving with mean measure $=-0.16$ logit and mean score $=$ 4.46. The immediate supervisor has placed the third ranking on the next and is a continuing learning skill with mean measure $=-0.09$ and min score $=4.44$; communication skills with mean measure $=0.12$ logit and mean score $=4.38$; teamwork skills with mean measure $=0.17$ and mean score $=4.36$; technology skills with mean measure $=0.38$ and mean score $=4.31$; and the final ranking construct is organization skill with mean measure $=$ 0.45 logit and mean score $=4.29$. The level analysis of employability skills constructs is shown in Table 5 .

Table 5. Analyze the Important Level of Employability Skills Construct at Quality and Assurance Unit

\begin{tabular}{cccc}
\hline EMPLOYABILITY SKILLS CONTRUCT & MEAN MEASURE (LOGIT) & MEAN SCORE & LEVEL \\
\hline Personal Quality & -0.86 & 4.60 & HIGH \\
Critical Thinking Skills and Problem Solving & -0.16 & 4.46 & HIGH \\
Continuous Learning Skills & -0.09 & 4.44 & HIGH \\
Communication Skills & 0.12 & 4.38 & HIGH \\
Teamwork Skills & 0.17 & 4.36 & HIGH \\
Technology Skills & 0.38 & 4.30 & HIGH \\
Organizational Skills & 0.45 & 4.29 & HIGH \\
\hline
\end{tabular}

\section{Discussion}

The main purpose of the study is to identify the importance level of employability skills construct required to improve the work performance based on the perception of the immediate supervisor's in the polytechnic electronic graduates' job role. To achieve the goal of this study, researchers used Winstep software to analyze seven constructs of employability skills i.e. communication skills; personal qualities; teamwork skills; critical thinking skills and problem solving; technology skills; organizational skills and continuous learning skills. The result of the analysis of the findings obtained through this questionnaire, the researcher tested all the methods and elements agreed by the respondents using a face-to-face questionnaire containing 31 items. Based on the overall analysis conducted, the researcher finally identified the importance level of construct of employability skills needed towards improving performance in four units of electrical and electronics industries namely research and development units, unit maintenance, unit production and unit quality and assurance. The following is a discussion of findings from the findings analysis.

\subsection{The Importance of Employability Skills Application}

The results of the analysis show that critical thinking skills and problem solving are the constructs of employability skills that are most preferred by immediate supervisors, especially in the Research and Development unit, Maintenance unit and Production unit and second in the Quality Assurance unit. The findings of the study by Bhatt (2015) prove that engineering is concerned with solving the problem of corporate customers. Problem solving skills are the most basic skills to venture into engineering because failure to solve problems will result in increased operating costs and company reputation. As such, engineering graduates need to have the analytical and critical thinking capabilities as Bhatt (2015) critical thinking is the backbone of the most important workplace skills and graduates who have it will be able to solve problems, make decisions, manage risks and creatively and potentially for career advancement.

Immediate supervisors in Quality Assurance units experience personal qualities as the most important and are the priorities of both employability skills that must be acquired by prospective graduates before entering the workplace in the Research and Development unit, Maintenance unit and Production unit. This finding is in line with the results of the study conducted by Ho (2015) where the employer puts a dimension of personality that includes loyalty and ethics followed by disciplined and has the best preferences. This finding is similar to the findings of Latisha and Surina (2010) that employers are looking for employees with high personal qualities. The findings are also in line with the findings of Abas-Mastura, Ombra A. Imam, et al. (2013) find that positive attitudes and behaviors are needed by employers. The failure of personal quality possession by graduates to address the issue raised in the report by Jobs Street Malaysia (2016) which shows that from 400 respondents 
comprising employers almost $68 \%$ stated that new workers demand high salaries. As a result, employers cannot offer employment to new graduates and this is a factor contributing to the unemployment rate in Malaysia. Graduates feel that they are great with graduation, but employers have the opposite. Therefore, emphasis should be placed on personal quality aspects during the teaching and learning process at the institutions of higher learning so that future graduates will have high personal qualities.

Immediate supervisors at the Research and Development unit and the Production unit put the importance of communicating communication skills at high levels in the third and fourth ranks in the Maintenance unit and Quality Assurance units. The findings of this study are in tandem with Bhatt (2015) which states that engineering graduates need to be good speakers and perhaps a good writer depends on work. They need to feel confident talking with the superior or by phone, and they may also need to write, enough to be understood in emails and scraps. The study by Quah et al. (2009) and Yuzainee et al. (2011) on the level of importance of employability skills in the industrial sector in Malaysia, found that the most important employability skills of industrial workers are communication skills and high confidence. This finding is similar to Hamdan and Nasharudin (2000), who also noted that graduates should master various communication techniques verbally, written and master the second language. This is important because by mastering the information liquidity communication skills will be avoided as well as enhancing self-confidence when dealing with multi-level organizational members.

Immediate supervisors also place a high level of possession of teamwork skills at high levels. Not as a result of study by Mohamad Sattar et al. (2009) on the importance of employability skills by 107 employers from five types of manufacturing industries including the electrical and electronics industries that put the importance of interpersonal skills such as leadership capabilities, teaching others and working with cultural diversity in the first ranking with the highest mean score. Immediate supervisors in Production units put the level of importance of teamwork skills into fourth and fifth ranks for Quality Assurance units while immediate supervisors in the Research and Development unit and Maintenance unit were ranked sixth. Results of the study by Yuzainee et al. (2011) also found that employers needed graduates who were able to work well with group members. The results of the study by Bhatt (2015) state that employer's value and encourage employees who show the ability to work well in groups and teams.

Subsequently the results showed that immediate supervisors in the Research and Development unit and the Production unit set the stage of organizational skills development at the highest level in ranking fourth, fifth rank in Maintenance unit and Production unit, and last rank in Quality Assurance unit. The results of this study are in line with the statement by Hamdan and Nasharudin (2000) which states that graduates should have the capability to master the organization's skills as graduates will not only face the technical environment but also face social environment. Hence, by mastering organizational skills, the role of assistant manager in making supervision will be more effective. In addition to mastering organizational skills, graduates are able to maximize the potential of each member so that organizational goals can be achieved.

The results also show that immediate supervisors in the Maintenance unit and Quality Assurance units put the level of importance of continuing learning skills at high levels in the third ranking and fifth and sixth ranks for the Research and Development units and the Production units. The findings of this study are in line with the statement by Hamdan and Nasharudin (2000) that the graduates should be able to perform self-directed learning to obtain information and capabilities in any work. This is especially important because the knowledge learned at technical institutions usually does not last long and quickly expires. Self-reading, thinking and self-reliance must be emphasized in the institution so that graduates are successful in achieving the latest technology and can change and take on the role of technology development. Analysis results show that immediate supervisors in the Research and Development unit, the Maintenance unit and the Production unit put the importance of constructing technology skills at a high level but in the last ranking. While the immediate supervisor in the Quality Assurance unit also placed it at a high level in the sixth ranking. The results of the study conducted by Gurvinder Kaur and Sharan Kaur (2008) on industrial employers in Malaysia found that the mastery of computer-based skills is needed in today's work environment.

In conclusion, it can be concluded that possession of employability skills is important for a prospective graduates to gain employment and remain and potentially improve their career in an organization. Despite the overall importance of the seven constructs of employability skills are at a high level based on the score but priority rankings are of different importance based on the unit in which a learner plays his role as a technician.

\section{Conclusion}

In conclusion, as the effort to strengthen the efforts of providing quality graduates, the study of employability requires continuous effort so that the institutions can learn the skills change, especially the employability skills 
required by the employers. The perception of the immediate supervisor at the workplace is very precise because they are the employability skills implementers and the priority importance of employability skills are different according to the field of work in tandem with the changing concept of the basic concept of employability skills that are now more work-oriented contexts (Sung, Ng, Loke, \& Ramos, 2013). This statement along with Stasz's (1997) study found that employability skills constructs cannot be seen in general across all occupations but instead it should be based on the role of work, especially those requiring high skills such as engineering. This is because the employer's job offer is dependent on the possession of appropriate employability skills by graduates for a desired job role (Dafou, 2009). The clarity of the concept of employability skills based on the job role will facilitate graduates to adapt to the wave of industrial change wave to the Industry Concept 4.0 with the application of the exact employability skills oriented in the polytechnic electrical engineering curriculum.

\section{References}

Abas-Mastura, M., Imam, O. A., \& Osman, S. (2013). Employability Skills and Task Performance of Employees in Government Sector. International Journal of Humanities and Social Science, 3(4), 150-162.

Ahn, Y. H., Pearce, A. R., \& Kwon, H. (2012). Key Competencies for U . S . Construction Graduates: Industry Perspective. Journal of Professional Issues In Engineering Education \& Practice () ASCE, (April), 123-130. https://doi.org/10.1061/(ASCE)EI.1943-5541

Australian Government Department of Education Employment and Workplace Realtions. (2008). Employability Skills : Fostering, Assessing and Reporting. Retrieved from http://www.nssc.natese.gov.au/_data/assets/ pdf_file/0008/69452/RTO_pamphlet_Employability_skills_fostering_assessing_and_reporting_web_versio n.pdf

Bax, M. R. N., \& Mohamood, M. R. (2005). The Year 2004 Polytechnic Convocation Survey. Proceedings of National Seminar the Development of Technology and Technical-Vocational Education and Training in an Era of Globalization: Trend and Issues. Kuala.

Bhatt, M. D. (2015). Soft Skills Become Complementary to Employability Skills for Engineering Students. International Journal of Research in Engineering, Science and Technologies (IJRESTs), 1(2), 2327.

Boyatzis, R. E. (2008). Competencies in the 21st century. Journal of Management Development, 27(1), 5-12. https://doi.org/10.1108/02621710810840730

Creswell, J. W. (2012). Educational Research Planning, Conducting and Evaluating Quantitative and Qualitative Research.

Dafou, E. (2009). Qualifications and skills: The organisational perspective. Journal of Education and Work, 22(2), 91-104. https://doi.org/10.1080/13639080902854003

DEST. (2006). Employability skills from framework to practice, an introductory guide for trainers and assessors. A report by the Australian Chamber of Commerce and Industry and the Business Council of Australia for the Department of Education, Science and Training, Canberra.

Evers, F. T., Rush, J. C., \& Berdrow, I. (1998). The bases of competence: Skills for lifelong learning and employability.

Fairuzza, Nazuir, M., \& Wahid. (2011). Employers 'Perception On Soft Skills Of Graduates: A Study Of Intel Elite Soft Skill Training. In International Conference on Teaching \& Learning in Higher Education.

Gurvinder Kaur, G. S., \& Sharan Kaur, G. S. (2008). Malaysian Graduates' Malaysian Employability Skills. UNITAR E-Journal, 4(1), 15-45.

Hamzah, M. S. G. B., Mohamed, H., \& Abdullah, S. K. (2012). The Senario From an Employer Perspective: Employability Profiles of Graduates. US-China Education Review, 7, 675-681.

Hasan, A. (2012). Instrumen Penilaian Pembimbing Dalam Pelaksanaan Pembelajaran Berasaskan Kerja (PBK) Pelajar Di Industri.

Ho, H. (2015). Matching University Graduates' Competences with Employers' Needs in Taiwan. International Education Studies, 8(4), 122-133. https://doi.org/10.5539/ies.v8n4p122

Husain, M. Y., Rasul, M. S., Mustapha, R., Malik, S. A., Amnah, R., \& Rauf, A. (2013). Jurnal Teknologi Full paper Tahap Kemahiran Employability Pelajar Kejuruteraan dari Perspektif, 1, 31-39.

Hussain, S. (2005). Meeting the Needs of Employers. Proceedings of National Seminar. The development of Technology and Technical-Vocational Education and Training in an Era of Globalization: Trend and Issues. 
Kuala Lumpur.

Izyan, M., Zainudin, Z., Saud, M. S., \& Nordin, M. S. (2012). Curriculum In TVET: Catalyst Towards Nations ' s Success. Journal of Technical, Vocational \& Engineering Education, 5(March), 20-27.

Johari, M. H., Zain, R. Md., Zaharim, A., Basri, H., \& Omar, M. Z. (2011). Perception and expectation toward engineering graduates by employers: A UKM study case. 2011 3rd International Congress on Engineering Education (ICEED), 203-207. https://doi.org/10.1109/ICEED.2011.6235390

Junaidah, H. (2012). Academic excellence as selection criteria among Malaysian employers. Higher Education, Skills and Work-Based Learning, 2(1), 63-73. https://doi.org/10.1108/20423891211197758

Kementerian Pengajian Tinggi. (2012). The National Graduate Employability Blueprint 2012-2017.

Kivinen, O., \& Silvennoinen, H. (2002). Changing relations between education and work: on the mechanisms and outcomes of the educational system. International Journal of Lifelong Education, 21(1), 44-54. https://doi.org/10.1080/02601370110099524

Konting, M. M. (1990). Kaedah Penyelidikan Pendidikan. Kuala Lumpur: Dewan Bahasa dan Pustaka.

Latisha Asmaak, \& Surina. (2010). Employability Awareness among Malaysian Undergraduates. International Journal of Business and Management, 5(8), 119-123. https://doi.org/10.5539/ijbm.v5n8p119

Martin, A. J., Milne-Home, J., Barrett, J., Spalding, E. \& Jones, G. (2000). Graduate satisfaction with university and perceived employment preparation. Journal of Education and Work, 13(2), 201-213. https://doi.org/10.1080/713676986

Nasir, A. N. M. (2012). Kajian Jurang Kemahiran Bukan Teknikal Antara Penguasaan Pekerja Mahir Sektor Elektronik Dan Kehendak Majikan.

Omar, N. H., Manaf, A. A., Mohd, R. H., Kassim, A. C., \& Aziz, K. A. (2012). Graduates 'Employability Skills Based on Current Job Demand through Electronic Advertisement. Asian Social Science, 8(9), 103-110. https://doi.org/10.5539/ass.v8n9p103

Pillai, S., Khan, M. H., Syahirah, I., \& Raphael, S. (2012). Enhancing employability through industrial training in the Malaysian context. Higher Education, (63), 187-204. https://doi.org/10.1007/s10734-011-9430-2

Prakash, P. (2012). Employability skills for engineers in the global market. 2012 IEEE International Conference on Engineering Education: Innovative Practices and Future Trends (AICERA), 1-6. https://doi.org/10.1109/AICERA.2012.6306683

Raybould, J., \& Sheedy, V. (2005). Are graduates equipped with the right skills in the employability stakes? Industrial and Commercial Training, 37(5), 259-263. https://doi.org/10.1108/00197850510609694

Rosenberg, S., Heimler, R., \& Morote, E.-S. (2012). Basic employability skills: a triangular design approach. Education + Training, 54(1), 7-20. https://doi.org/10.1108/00400911211198869

Sattar, M., Md Yusof, N., Rashid, M., \& Amnah, R. (2009). Peranan Institusi Pendidikan Teknikal Dalam Pemupukan Kemahiran ‘Employability’ Pelajar. Jurnal Teknologi, $50(50$ (E)), 113-127.

Sattar, M., Ismail, M., Napsiah, Rashid, M., \& Amnah, R. (2009). Importance of Employability Skills as Perceived by Employers of Malaysian Manufacturing Industry. Journal of Applied Sciences Research, 5(12), 2059-2066.

Science Technology Engineering and Mathematics Network (STEMNET). (2013). Top 10 Employability Skills. Retrieved from http://www.nationalstemcentre.org.uk/dl/96d471574a74b43749b5209379c7066a8c324409/ 3058-Employability_skills_guide.pdf

Selvadurai, S., Ah Choy, E., \& Maros, M. (2012). Generic Skills of Prospective Graduates from the Employers' Perspectives. Asian Social Science, 8(12), 295-303. https://doi.org/10.5539/ass.v8n12p295

Stasz, C. (1997). Do Employers Need the Skills They Want? Evidence from technical work. Journal of Education and Work, 10(3), 205-223. https://doi.org/10.1080/1363908970100301

Sung, J., Ng, M. C. M., Loke, F., \& Ramos, C. (2013). The nature of employability skills: empirical evidence from Singapore. International Journal of Training and Development, 17(3), 176-193. https://doi.org/10.1111/ijtd.12008

Talib, H. S. dan N. (2000). Cabaran Era Globalisasi Ke Atas Warga Pendidikan Di Malaysia. Jurnal Pendidikan UTM, Fakulti Pendidikan, Jil 6, 35-46. 
Talib, R. (2009). Pembinaan dan Pengesahan Instrumen Ujian Literasi Pentaksiran. Tesis Ph.D. UTM

Tetreault, P. A. (1997). Preparing students for work. Adult Learning, 8, 10-13. https://doi.org/10.1177/104515959700800408

The Conference Board of Canada. (2000). Employability Skills $2000+$.

Tymon, A. (2011). The student perspective on employability. Studies in Higher Education, (June 2013), 1-16. https://doi.org/10.1080/03075079.2011.604408

Yusoff, Y. M., Omar, M. Z., Zaharim, A., Mohamed, A., Muhamad, N., \& Mustapha, R. (2010). Enhancing Employability Skills through Industrial Training Programme. In Latest Trends on ENGINEERING EDUCATION (pp. 398-403).

Yusoff, Y. M., Zaharim, A., \& Omar, M. Z. (2011). Employability skills for an entry-level engineer as seen by Malaysian employers. In 2011 IEEE Global Engineering Education Conference (EDUCON) (pp. 80-85). Ieee. https://doi.org/10.1109/EDUCON.2011.5773117

\section{Copyrights}

Copyright for this article is retained by the author(s), with first publication rights granted to the journal.

This is an open-access article distributed under the terms and conditions of the Creative Commons Attribution license (http://creativecommons.org/licenses/by/4.0/). 